\title{
Manajemen Modal Kerja dan Kinerja Perusahaan pada Perusahaan Perdagangan Eceran di Indonesia
}

\author{
Dania Olfimarta ${ }^{\mathrm{a}}$ and Seto Sulaksono Adi Wibowo ${ }^{\mathrm{b}, *}$ \\ a Manajemen Bisnis, Politeknik Negeri Batam, daniaolfi@yahoo.com, Indonesia \\ ${ }^{\mathrm{a}}$ Manajemen Bisnis, Politeknik Negeri Batam, seto@polibatam.ac.id, Indonesia
}

\begin{abstract}
Manajemen modal kerja adalah manajemen dari aktiva lancar dan hutang lancar. Tujuan manajemen modal kerja adalah mengelola aktiva lancar dan hutang lancar sehingga diperoleh modal kerja yang layak dan menjamin tingkat likuiditas perusahaan. Penelitian ini bertujuan untuk meneliti pengaruh manajemen modal kerja yang diproksikan dengan perputaran modal kerja, perputaran kas, perputaran persediaan, perputaran piutang terhadap kinerja perusahaan. Data yang digunakan adalah data sekunder berupa laporan keuangan perusahaan perdagangan eceran yang terdaftar di Bursa Efek Indonesia (BEI) periode 20122016. Metode pengambilan sampel menggunakan teknik purposive sampling. Alat analisis yang digunakan adalah analisis regresi linier sederhana serta uji parsial (uji statistik t). Hasil penelitian menemukan perputaran modal kerja berpengaruh positif signifikan terhadap kinerja perusahaan. Perputaran kas berpengaruh positif dan tidak signifikan terhadap kinerja perusahaan. Perputaran persediaan berpengaruh positif dan tidak signifikan terhadap kinerja perusahaan. Penelitian selanjutnya diharapkan menambah proksi maupun variabel independen lainnya yang diduga berpengaruh dalam kinerja perusahaan dan memperluas sektor perusahaan sehingga hasil penelitan tidak hanya memiliki implikasi untuk sektor perdagangan eceran saja tetapi juga memiliki implikasi untuk perusahaan lainnya di sektor yang berbeda dan memperhitungkan ukuran perusahaan dan melihat pengaruhnya terhadap hasil penelitian selanjutnya.
\end{abstract}

Keywords: perputaran modal kerja, perputaran kas, perputaran persediaan, perputaran piutang, dan kinerja perusahaan

\section{Pendahuluan}

Manajemen modal kerja adalah kegiatan yang mencakup seluruh fungsi manajemen mengenai aktiva lancar dan kewajiban jangka pendek suatu perusahaan. Manajemen modal kerja bertujuan untuk mengawasi jalannya perusahaan dalam memenuhi kewajiban jangka pendeknya dan sejauh mana operasi perusahaan dapat dibiayai dengan sumber pendanaan yang ada, sehingga kekuatan membayar semakin besar daripada kewajiban finansialnya yang harus dipenuhi oleh pihak lain. Manajemen modal memiliki peran penting dalam mencapai tujuan perusahaan karena sebagian besar waktu yang dimiliki manajer keuangan dialokasikan untuk manajemen modal kerja dan lebih dari lima puluh persen dari total aset umumnya diinvestasikan pada aktiva lancar, sehingga antara peningkatan penjualan dengan kebutuhan investasi pada aktiva lancar berkaitan langsung dengan modal kerja (Solano et al., 2013).

Perputaran modal kerja merupakan salah satu aspek penting dari keseluruhan manajemen keuangan. Perputaran modal kerja tersebut tergantung kepada masing-masing komponen modal kerja seperti perputaran kas, perputaran piutang dan perputaran persediaan. Perusahaan secara umum harus mempertahankan aktiva lancar yang lebih besar dari pada jumlah hutang lancar, sehingga perputaran modal kerja dapat meningkat (Rahma, 2013).

Pada umumnya setiap perusahaan yang menjalankan usaha selalu membutuhkan modal kerja yang mencukupi. Keberadaan modal kerja sangat penting bagi perusahaan untuk menunjang seluruh kegiatannya, dan dengan adanya efisiensi dan

\footnotetext{
*Corresponding author. E-mail: seto@polibatam.ac.id
} 
efektivitas modal kerja maka diharapkan perusahaan dapat meningkatkan profitabilitasnya. Hal ini disebabkan oleh semakin cepat perputaran modal kerja, maka semakin cepat pula modal kerja kembali menjadi kas. Tingkat modal kerja yang lebih tinggi memungkinkan perusahaan untuk meningkatkan penjualan mereka dan mendapatkan potongan harga yang lebih besar untuk pembayaran awal sehingga dapat meningkatkan nilai perusahaan. Manajemen modal kerja memainkan peran penting dalam kinerja yang lebih baik pada perusahaan (Yang et al., 2014).

Keputusan modal kerja mempengaruhi kinerja perusahaan secara signifikan sehingga apabila keputusan yang diambil baik maka hasil kinerja perusahaan juga baik dan begitu juga sebaliknya. Peneliti terdahulu menemukan bahwa perusahaan dengan nilai yang lebih tinggi memegang investasi secara signifikan lebih tinggi dalam modal kerja daripada perusahaan dengan nilai-nilai yang lebih rendah (Kim et al., 1990). Perusahaan dengan keuntungan yang lebih tinggi tidak termotivasi untuk mengelola modal kerja dan kinerja perusahaan karena mereka cenderung sudah puas dengan hasil tinggi yang telah dicapai sehingga penelitian mereka menunjukkan bahwa ada hubungan negatif antara modal kerja dan kinerja perusahaan (Shin et al., 1998).

Tingkat modal kerja yang tinggi artinya terdapat cukup banyak likuiditas yang tidak menciptakan manfaat ekonomi yang lebih, yang menyiratkan bahwa perusahaan mungkin kurang adanya peluang dalam investasi dan akan. mempengaruhi pengembangan potensi. Perusahaan harus mempertahankan tingkat modal kerja yang tepat agar kinerja di perusahaan baik, sehingga perusahaan perlu menyesuaikan kepemilikan dan komposisi modal kerja untuk beradaptasi dengan kebutuhan pasar.

Perusahaan perdagangan eceran merupakan jembatan yang menghubungkan produsen ke pelanggan, dan perusahaan perdagangan eceran merupakan yang paling memberi perhatian lebih pada modal kerja daripada perusahaan lainnya. Perusahaan perdagangan eceran di Indonesia memiliki tingkat pertumbuhan Produk Domestik Bruto (PDB) sekitar 5\% pertahun. Menurut Asosiasi Perusahaan Ritel Indonesia (APRINDO), pertumbuhan bisnis ritel di Indonesia antara $10 \%$ sampai $15 \%$ per tahun.

Penelitian ini merupakan replikasi dari penelitian yang dilakukan oleh (Yang et al., 2014) dengan hasil yang menyatakan bahwa ada pengaruh antara manajemen modal kerja dan kinerja perusahaan. Penelitian ini berbeda dengan penelitian tersebut karena menggunakan sampel perusahaan di Indonesia pada tahun 2012-2016. Berdasarkan hasil penelitian tersebut, peneliti terarik untuk melakukan penelitian yang sama di Indonesia. Dengan tujuan untuk mengetahui apakah hasil dari penelitian tersebut akan sama jika dilakukan di perusahaan perdagangan eceran yang terdaftar di Bursa Efek Indonesia (BEI).

\section{Kajian Literatur}

\section{Resource-based theory}

Wernerfelt (1984) menjelaskan bahwa menurut pandangan resource based theory, perusahaan memperoleh keunggulan kompetitif dan kinerja keuangan yang baik dengan cara memiliki, menguasai, dan memanfaatkan aset-aset strategis yang penting, termasuk aset berwujud maupun aset tidak berwujud. Konsep resource based theory, jika perusahaan mampu mengelola sumber daya secara efektif maka akan dapat menciptakan keunggulan kompetitif dibanding para pesaing. Sumber daya manusia yang memiliki keterampilan dan kompetensi tinggi merupakan keunggulan kompetitif bagi perusahaan apabila dapat dimanfaatkan dan mengelola potensi yang dimiliki karyawan dengan baik, maka hal ini dapat meningkatkan produktivitas karyawan. Adanya peningkatan produktivitas, maka kinerja perusahaan akan meningkat dan dengan adanya pengelolaan sumber daya yang efektif tersebut maka pemakaian sumber daya atau pengeluaran akan lebih efektif dan efisien.

\section{Agency theory}

Menurut Jensen \& Meckling (1976), teori keagenan adalah sebuah kontrak antara manajemen (agen) dengan pemilik (prinsipal). Agar hubungan kontraktual ini dapat berjalan lancar, pemilik akan mendelegasikan otoritas pembuatan keputusan kepada manajer. Perencanaan kontrak yang tepat bertujuan untuk menyelaraskan kepentingan manajer dan pemilik dalam hal konflik dan kepentingan, hal ini merupakan inti dari teori keagenan. Menurut Scott (2000), terdapat dua macam asimetri informasi yaitu:

a. Adverse selection, adalah para manajer serta orang-orang dalam lainnya yang pada dasarnya mengetahui lebih banyak keadaan dan prospek perusahaan dibandingkan para pemegang saham atau pihak luar. Informasi yang mengandung fakta yang akan digunakan pemegang saham untuk mengambil keputusan tidak diberikan secara detail oleh manajer. 
b. Moral hazard, adalah kegiatan yang dilakukan oleh seorang manajer tidak seluruhnya diketahui oleh pemegang saham maupun pemberi pinjaman. Sehingga manajer dapat melakukan tindakan di luar sepengetahuan pemegang saham yang melanggar kontrak dan sebenarnya secara etika atau etika tidak layak dilakukan.

Jensen \& Meckling (1976) menyatakan bahwa konflik keagenan disebabkan oleh pembuatan keputusan aktivitas pencairan dana (financing decision) dan pembuatan keputusan bagaimana dana tersebut diinvestasikan. Selain itu, perspektif teori agensi laba sangat rentan terhadap manipulasi oleh manajemen. Informasi laporan keuangan yang disampaikan tepat waktu akan mengurangi asimetri informasi yang berkaitan erat dengan agency theory. Jensen \& Meckling (1976), menjelaskan biaya keagenan dalam tiga jenis yaitu:

a. Biaya Monitoring (monitoring cost), merupakan biaya yang dikeluarkan untuk melakukan pengawasan terhadap aktivitas-aktivitas yang dilakukan oleh agen.

b. Biaya Bonding (bonding cost), merupakan biaya untuk menjamin bahwa agen tidak akan bertindak merugikan prinsipal, atau dengan kata lain untuk meyakinkan agen, bahwa prinsipal akan memberikan kompensasi jika agen benar-benar melakukan tindakan tersebut.

c. Biaya Kerugian Residual (residual loss), yaitu nilai uang yang ekuivalen dengan pengurangan kemakmuran yang dialami oleh prinsipal akibat perbedaan kepentingan.

\section{Manajemen modal kerja}

Manajemen modal kerja merupakan salah satu aspek yang harus diperhatikan dalam perusahaan. Perusahaan tidak dapat mempertahankan tingkat modal kerja yang memuaskan maka kemungkinan perusahaan akan berada dalam keadaaan insolvent (tidak mampu membayar kewajiban-kewajiban yang sudah jatuh tempo). Aktiva lancar harus cukup besar untuk dapat menutup hutang lancar sehingga menggambarkan tingkat keamanan (margin of safety) yang memuaskan. Manajemen modal kerja adalah kegiatan yang mencakup semua fungsi manajemen atas aktiva lancar dan kewajiban jangka pendek perusahaan yang terdapat dalam perusahaan agar mampu membiayai pengeluaran atau operasi perusahaan (Esra \& Apriweni, 2002). Pengertian tersebut dapat disimpulkan bahwa perhatian utama dalam manajemen modal kerja adalah pada manajemen aktiva lancar perusahaan, yaitu kas, sekuritas, piutang dan persediaan serta pendanaan (terutama kewajiban lancar) yang diperlukan untuk mendukung aktiva lancar. Martono \& Harjito (2004) mengemukakan beberapa alasan yang mendasari pentingnya manajemen modal kerja, yaitu:

a. Aktiva lancar dari perusahaan baik perusahaan manufaktur maupun perusahaan jasa memiliki jumlah yang cukup besar dibanding dengan jumlah aktiva secara keseluruhan.

b. Untuk perusahaan kecil, hutang jangka pendek merupakan sumber utama bagi pendanaan eksternal. Perusahaan ini tidak memiliki akses pada pasar modal untuk pendanaan jangka panjangnya.

c. Manajer keuangan dan anggotanya perlu memberikan porsi waktu yang sesuai untuk pengelolan tentang hal-hal yang berkaitan dengan modal kerja.

d. Keputusan modal kerja berdampak langsung terhadap tingkat risiko, laba, dan harga saham perusahaan.

e. Adanya hubungan langsung antara pertumbuhan penjualan dengan kebutuhan dana untuk membelanjai aktiva lancar.

\section{Perputaran modal kerja}

Menentukan jumlah modal kerja yang efisien, terlebih dahulu diukur dari elemen-elemen modal kerja. Dalam pengelolaan modal kerja perlu diperhatikan tiga elemen utama modal kerja, yaitu kas, piutang dan persediaan. Dari semua elemen modal kerja dihitung perputarannya. Semakin cepat tingkat perputaran masing-masing elemen modal kerja, maka modal kerja dapat dikatakan efisien. Tetapi jika perputarannya semakin lambat, maka penggunaan modal kerja dalam perusahaan kurang efisien. (Esra \& Apriweni, 2002).

Modal kerja selalu dalam keadaan operasi atau berputar dalam perusahaan selama perusahaan yang bersangkutan dalam keadaan usaha. Periode perputaran modal kerja (working capital turnover period) dimulai pada saat kas diinvestasikan dalam komponen-komponen modal kerja sampai pada saat kembali lagi menjadi kas. Semakin pendek periode tersebut berarti semakin cepat perputaran modal kerja dan efisiensi penggunaan modal kerja perusahaan tinggi. Sebaliknya semakin panjang periode perputaran modal kerja berarti semakin lambat 
perputaran modal kerja dan efisiensi penggunaan modal kerja perusahaan rendah. Lama periode perputaran modal kerja tergantung kepada berapa lama periode perputaran dari masing-masing komponen dari modal kerja tersebut (Riyanto, 2001).

\section{Perputaran kas}

Kas merupakan aktiva paling likuid atau merupakan salah satu unsur modal kerja yang paling tinggi likuiditasnya yang berarti bahwa semakin besar jumlah kas yang dimiliki suatu perusahaan akan semakin tinggi pula tingkat likuiditasnya. Ini berarti bahwa perusahaan mempunyai risiko yang lebih kecil untuk tidak dapat memenuhi kewajiban finansialnya. Tetapi ini tidak berarti bahwa perusahaan harus mempertahankan persediaan kas yang sangat besar, karena semakin besar kas akan menyebabkan banyaknya uang menganggur sehingga akan memperkecil keuntungannya. Tetapi suatu perusahaan yang hanya mengejar keuntungan tanpa memperhatikan likuiditasnya, maka perusahaan tersebut akan dalam keadaan likuid jika sewaktuwaktu ada tagihan (Riyanto,2001). Dari uraian tersebut dapat disimpulkan bahwa kas sangat berperan dalam menentukan kelancaran kegiatan perusahaan, oleh karena itu kas harus direncanakan dan diawasi dengan baik dari segi penerimaan dan pengeluarannya.

\section{Perputaran persediaan}

Inventory atau persediaan barang sebagai elemen yang utama dari modal kerja merupakan aktiva yang selalu dalam keadaan berputar, di mana secara terus menerus mengalami perubahan. Masalah investasi dalam inventory merupakan masalah pembelanjaan aktif, seperti halnya investasi dalam aktiva-aktiva lainnya. Masalah penentuan besar investasi atau alokasi modal dalam inventory mempunyai efek yang langsung terhadap keuntungan perusahaan. Kesalahan dalam penetapan besarnya investasi dalam inventory akan menekan keuntungan perusahaan.

Investasi dalam inventory yang terlalu besar dibandingkan dengan kebutuhan akan memperbesar beban bunga, memperbesar biaya penyimpanan dan pemeliharaan di gudang, memperbesar kemungkinan kerugian karena kerusakan, turunnya kualitas, sehingga semuanya ini akan memperkecil keuntungan perusahan. Demikian sebaliknya, adanya investasi yang terlalu kecil dalam inventory juga akan mempunyai efek yang menekan keuntungan perusahaan (Riyanto, 2001).

\section{Perputaran piutang}

Perputaran piutang merupakan rasio aktivitas yaitu rasio yang mengukur kemampuan perusahaan dalam menggunakan dana yang tersedia yang tercermin dalam perputaran modal. Rasio perputaran piutang memberikan pandangan mengenai kualitas piutang perusahaan dan seberapa berhasilnya perusahaan dalam penagihannya, semakin cepat perputaran piutang menandakan bahwa modal dapat digunakan secara efisien.

Perputaran piutang ini menunjukkan berapa kali sejumlah modal yang tertanam dalam piutang yang berasal dari penjualan kredit berputar dalam satu periode. Dengan kata lain, rasio perputaran piutang bisa diartikan berapa kali suatu perusahaan dalam setahun mampu "membalikkan" atau menerima kembali kas dari piutangnya, semakin tinggi tingkat perputaran piutang berarti semakin cepat dana yang diinvestasikan pada piutang dagang dapat ditagih menjadi uang tunai atau menunjukkan model kerja yang tertanam dalam piutang rendah. Sebaliknya jika tingkat perputaran piutang rendah berarti piutang dagang membutuhkan waktu yang lebih lama untuk dapat ditagih dalam bentuk uang tunai.

\section{Gross profit margin}

Rasio gross profit margin atau margin laba kotor berguna untuk mengetahui keuntungan kotor perusahaan dari setiap barang yang dijual. Gross profit margin sangat dipengaruhi oleh harga pokok penjualan. Apabila harga pokok penjualan meningkat maka gross profit margin akan menurun, begitu pula sebaliknya. Rasio ini mengukur efisiensi pengendalian harga pokok atau biaya produksinya dan mengindikasikan kemampuan perusahaan untuk berproduksi secara efisien. Semakin tinggi margin laba kotor perusahaan, maka semakin bagus, karena itu artinya biaya produksi perusahaan itu rendah. Dan sebaliknya, semakin rendah margin laba kotor semakin tinggi biaya produksi yang ditanggung perusahaan.

\section{Pengembangan hipotesis}

Dalam penelitian pengaruh manajemen modal kerja terhadap kinerja perusahaan di dalam laporan tahunan, menggunakan empat variabel penelitian untuk 
mengukur manajemen modal kerja perusahaan, yaitu perputaran modal kerja, perputaran kas, perputaran persediaan dan perputaran piutang sedangkan untuk mengukur kinerja digunakan gross profit margin.

\section{Pengaruh perputaran modal kerja terhadap kinerja perusahaan}

Perputaran modal kerja adalah kemampuan modal kerja berputar dalam suatu periode siklus kas dari perusahaan. Perputaran modal kerja mengukur efektifitas penggunaan aktiva lancar untuk menghasilkan penjualan (Riyanto, 2011). Perputaran modal kerja diukur dengan menggunakan rasio penjualan terhadap aktiva lancar (working capital turnover ratio) yaitu membandingan antara penjualan dengan jumlah keseluruhan total aktiva lancar perusahaan pada periode tertentu. Semakin tinggi tingkat perputaran tersebut semakin efektif penggunaan modal kerja. Hal tersebut menunjukkan banyaknya penjualan yang diperoleh perusahaan.

Penjualan yang tinggi meningkatkan profitabilitas perusahaan sehingga berdampak baik bagi kinerja perusahaan dan sebaliknya tingkat perputaran yang rendah menunjukkan adanya kelebihan modal kerja yang menunjukkan bahwa penggunaan modal kerja tidak efektif sehingga menurunkan profitabilitas perusahaan dan tidak berdampak baik bagi kinerja perusahaan. Berdasarkan penjelasan di atas dapat dirumuskan hipotesis sebagai berikut:

H1: Perputaran modal kerja (working capital turnover) berpengaruh positif terhadap kinerja perusahaan (gross profit margin)

\section{Pengaruh perputaran kas terhadap kinerja perusahaan}

Perputaran kas merupakan perbandingan antara penjualan dengan jumlah kas rata-rata. Perputaran kas menunjukkan kemampuan kas dalam menghasilkan pendapatan sehingga dapat dilihat berapa kali uang kas berputar dalam satu periode tertentu. Perputaran kas akan baik jika perputarannya semakin tinggi, berarti semakin tinggi efisiensi penggunaan kasnya dan keuntungan yang diperoleh akan semakin besar dan menunjukkan bahwa kinerja perusahaan baik (Riyanto, 2001).

Tinggi rendahnya perputaran kas akan mempengaruhi profitabilitasnya, jika semakin tinggi perputaran kasnya, maka profitabilitasnya semakin tinggi juga, sehingga makin cepat kembalinya kas masuk pada perusahaan. Kas akan dapat dipergunakan kembali untuk membiayai kegiatan operasional sehingga tidak mengganggu kondisi keuangan perusahaan. Berdasarkan penjelasan di atas dapat dirumuskan hipotesis sebagai berikut:

H2: Perputaran kas (cash turnover) berpengaruh positif terhadap kinerja perusahaan (gross profit margin)

\section{Pengaruh perputaran persediaan terhadap kinerja perusahaan}

Kecepatan pengembalian kas melalui penjualan diperlukan suatu perputaran persediaan yang baik, untuk mengukur efisiensi persediaan maka perlu diketahui perputaran persediaan (inventory turnover) yang terjadi dengan membandingkan antara harga pokok penjualan (HPP) dengan nilai rata-rata persediaan yang dimiliki (Munawir, 2004). Perputaran persediaan menunjukkan berapa kali dana yang tertanam dalam persediaan berputar dalam suatu periode. Semakin tinggi tingkat perputaran persediaan akan memperkecil risiko terhadap kerugian yang disebabkan karena penurunan harga atau karena perubahan selera konsumen, di samping itu akan menghemat ongkos penyimpanan dan pemeliharaan terhadap persediaan tersebut.

Rasio ini merupakan indikasi yang cukup popular untuk menilai efisisensi operasional, yang memperlihatkan seberapa baiknya manajemen mengontrol modal yang ada pada persediaan. Ini berarti bahwa semakin tinggi perputaran persediaan maka semakin besar pula keuntungan yang diperoleh dan semakin menunjukkan kinerja perusahaan yang baik. Besarnya hasil perhitungan perputaran persediaan menunjukkan tingkat kecepatan perputaran persediaan menjadi kas atau piutang dagang serta menunjukkan berapa kali persediaan tersebut berganti dalam arti dibeli dan dijual kembali. Berdasarkan penjelasan di atas dapat dirumuskan hipotesis sebagai berikut:

H3: Perputaran persediaan (inventory turnover) berpengaruh positif terhadap kinerja perusahaan (gross profit margin)

\section{Pengaruh perputaran piutang terhadap kinerja perusahaan}

Perputaran piutang merupakan rasio aktivitas yaitu rasio yang mengukur kemampuan perusahaan dalam menggunakan dana yang tersedia yang tercermin dalam perputaran modal. Rasio perputaran piutang memberikan pandangan mengenai kualitas piutang 
perusahaan dan seberapa berhasilnya perusahaan dalam penagihannya. Semakin cepat perputaran piutang menandakan bahwa modal dapat digunakan secara efisien dan semakin baik pula kinerja perusahaan. Hal tersebut sejalan dengan pernyataan yang dikemukakan oleh (Kasmir, 2011) bahwa rasio perputaran piutang (receivable turnover) digunakan untuk mengukur berapa lama penagihan piutang selama satu periode atau berapa kali dana yang ditanam dalam piutang tersebut berputar dalam satu periode. Semakin tinggi rasio ini menunjukkan bahwa modal kerja yang ditanamkan dalam piutang semakin rendah dan tentunya kondisi ini baik bagi perusahaan. Berdasarkan penjelasan di atas dapat dirumuskan hipotesis sebagai berikut:

H4: Perputaran piutang (receivable turnover) berpengaruh positif terhadap kinerja perusahaan (gross profit margin)

\section{Kerangka pemikiran}

Berdasarkan ketiga hipotesis di atas, berikut ini adalah kerangka pemikiran yang dibentuk dalam penelitian ini:

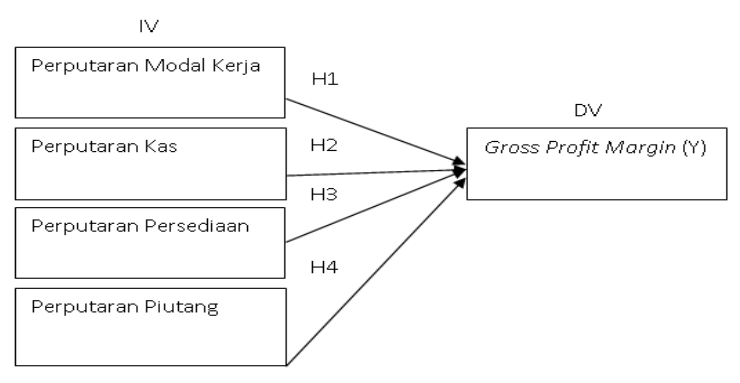

Gambar 1

Kerangka pemikiran

\section{Metode Penelitian}

\section{Data dan sampel}

Berdasarkan langkah-langkah penelitian yang sudah dirancang dan direncanakan sejak awal serta terdapatnya hipotesis maka penelitian ini dapat dikategorikan ke dalam metode penelitian kuantitatif. Metode penelitian secara kuantitatif ialah karena dalam proses pengukurannya dijabarkan melalui beberapa hal seperti: komponen masalah, variabel dan indikator. Pengukuran tersebut merupakan titik fokus dalam pengukuran untuk memperoleh data sampai akhir penelitian. Jenis data yang digunakan dalam penelitian ini adalah data sekunder dengan metode cross section.

Teknik yang digunakan dalam penarikan sampel ini adalah sampling nonprobabilitas yaitu purposive sampling berdasarkan judgment atau kriteria. Kriteria yang digunakan adalah perusahaan perdagangan eceran yang listing di Bursa Efek Indonesia (BEI), laporan keuangan yang menggunakan mata uang rupiah, menggunakan periode yang berakhir pada tanggal 31 Desember dan memiliki data yang lengkap terkait dengan variabel penelitian, dan perusahaan yang mengalami laba (keuntungan).

\section{Variabel penelitian dan pengukurannya}

Variabel dependen dalam penelitian ini adalah kinerja perusahaan dengan proksi gross profit margin. Gross profit margin yaitu rasio yang mengukur efisiensi pengendalian harga pokok atau biaya produksinya, mengindikasikan kemampuan perusahaan untuk berproduksi secara efisien. Gross profit margin merupakan persentase laba kotor dibandingkan dengan sales. Semakin besar gross profit margin semakin baik keadaan operasi perusahaan, karena hal ini menunjukkan bahwa harga pokok penjualan relatif lebih rendah dibandingkan dengan sales, demikian pula sebaliknya, semakin rendah gross profit margin maka semakin kurang baik operasi perusahaan.

Perputaran modal kerja (working capital turnover) adalah rasio yang menunjukkan hubungan antara modal kerja dengan penjualan dan menunjukkan banyaknya penjualan yang dapat diperoleh perusahaan untuk tiap rupiah modal kerja. Perbandingan antara penjualan dengan jumlah rata-rata kas menggambarkan tingkat perputaran kas (cash turnover). Perputaran kas merupakan kemampuan kas dalam menghasilkan pendapatan sehingga dapat dilihat berapa kali uang kas berputar dalam satu periode tertentu.

Perputaran persediaan (inventory turnover) berapa kali dana yang tertanam dalam persediaan berputar dalam suatu periode. Mengukur efisiensi persediaan maka perlu diketahui perputaran persediaan yang terjadi dengan membandingkan antara harga pokok penjualan (HPP) dengan nilai rata-rata persediaan yang dimiliki. Rasio ini menggambarkan kualitas piutang perusahaan dan kesuksesan perusahaan dalam penagihan piutang yang dimiliki. Semakin tinggi rasio ini, akan semakin baik kemampuan perusahaan dalam menagih piutang yang dimiliki. 


\section{Teknik analisis data}

Pengujian hipotesis penelitian dilakukan dengan menggunakan analisis regresi linear sederhana dengan program SPSS 17. Sebelum dilakukan analisis regresi tersebut, data harus memenuhi syarat uji asumsi klasik.

\section{Statistik deskriptif}

Statistik deskripstif memberikan gambaran atau deskripsi suatu data yang dilihat dari nilai rata-rata (mean), standard deviasi, varian, maksimum, minimum, sum, range, kurtosis dan skewness (Ghozali, 2011). Analisis deskriptif digunakan untuk menggambarkan dan mendeskripsikan variabelvariabel yang digunakan dalam penelitian ini. Analisis deskriptif dilakukan dengan menggunakan statistik deskriptif yang menghasilkan nilai rata-rata, maksimum, minimum, dan standar deviasi untuk mendeskripsikan variabel penelitian sehingga secara kontekstual mudah dimengerti.

\section{Pengujian hipotesis}

Menurut Sugiyono (2009), regresi linear sederhana adalah metode statistik yang berfungsi untuk menguji sejauh mana hubungan sebab akibat antara variabel faktor penyebab (x) terhadap variabel akibatnya. Faktor Penyebab pada umumnya dilambangkan dengan $\mathrm{x}$ atau disebut juga dengan predictor sedangkan variabel akibat dilambangkan dengan y atau disebut juga dengan response. Regresi linear sederhana atau sering disingkat dengan simple linear regression (SLR) juga merupakan salah satu metode statistik yang dipergunakan dalam produksi untuk melakukan peramalan ataupun prediksi tentang karakteristik kualitas maupun kuantitas. Persamaan yang diperoleh dari regresi sederhana sebagai berikut:

$$
\mathrm{Y}=\alpha+\beta \times
$$

$$
\begin{aligned}
& \text { GPM }=\alpha+\beta 1 \mathrm{WCT} \\
& \text { GPM }=\alpha+\beta 2 \mathrm{CT} \\
& \text { GPM }=\alpha+\beta 3 \mathrm{IT} \\
& \text { GPM }=\alpha+\beta 3 \mathrm{RT}
\end{aligned}
$$

(Model 1)

(Model 3)

(Model 4)

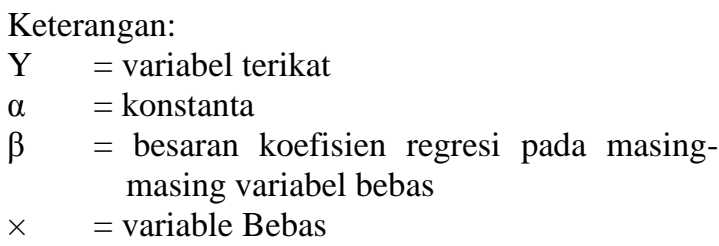

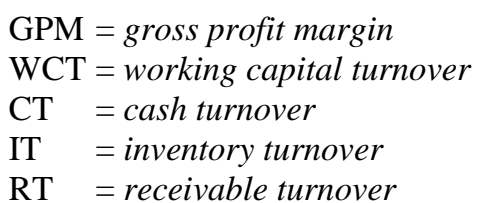

Pengujian hipotesis dalam penelitian ini menggunakan uji statisik t. Uji statistik t digunakan untuk menguji hipotesis pertama, hipotesis kedua, dan hipotesis ketiga. Menurut Ghozali (2012), uji statistik $\mathrm{t}$ bertujuan untuk mengetahui signifikansi peran secara parsial antara variabel independen terhadap variabel dependen dengan mengasumsikan bahwa independen lain dianggap konstan. Jika nilai signifikansi probabilitas $<0,05$ berarti terdapat pengaruh yang signifikan antara variabel independen secara parsial dengan variabel dependen (Ghozali, 2012). Hipotesis pertama, kedua, dan ketiga terdukung apabila koefisien regresi bernilai positif dan nilai signifikasi t kurang dari 5\%, sedangkan apabila koefisien regresi bernilai negatif atau nilai $\mathrm{t}$ lebih dari 5\% maka hipotesis tersebut tidak terdukung.

\section{Pembahasan}

Objek penelitian yang digunakan dalam penelitian ini adalah perusahaan perdagangan eceran yang terdaftar di Bursa Efek Indonesia (BEI) periode 20122016. Pemilihan sampel berdasarkan beberapa karakteristik yaitu perusahaan perdagangan eceran yang listing di BEI, laporan keuangan yang menggunakan mata uang rupiah, menggunakan periode yang berakhir pada tanggal 31 Desember, memiliki data yang lengkap terkait dengan variabel penelitian, dan perusahaan yang mengalami laba. Penentuan sampel pada penelitian ini dapat dilihat pada Tabel 1 berikut ini:

Tabel 1

Hasil Penentuan Sampel

\begin{tabular}{lc}
\hline \multicolumn{1}{c}{ Kriteria } & Jumlah \\
\hline Perusahaan perdagangan terdaftar di BEI 2012-2016 & 120 \\
Laporan keuangan mengunakan selain rupiah & $(10)$ \\
Laporan keuangan selain periode berakhir 31 Desember & $(10)$ \\
Laporan keuangan tidak ditemukan & $(20)$ \\
Mengalami kerugian & $(5)$ \\
Jumlah laporan keuangan dijadikan sampel & 75 \\
\hline
\end{tabular}

Statistik deskriptif

Analisis statistik deskriptif digunakan untuk memberikan gambaran atau deskripsi suatu data yang 
dilihat dari nilai meliputi nilai rata-rata (mean), minimum, maksimum, dan standar deviasi dari gross profit margin, working capital turnover, cash turnover, inventory turnover, receivable turnover. Hasil statistik deskriptif sampel yang digunakan dalam penelitian ini dapat dilihat pada Tabel 2 sebagai berikut:

Tabel 2

Statistik Deskriptif

\begin{tabular}{cccccc}
\hline Variabel & $\mathrm{N}$ & Min & Max & Mean & Std. Deviation \\
\hline GPM & 33 & 291.175 & 796.792 & 2.5610 & 2.35810 \\
PMK & 33 & 707.344 & 783.802 & 1.0010 & 2.09810 \\
PK & 33 & .06 & 6.03 & 2.0106 & 1.11441 \\
PP & 33 & .11 & 29.33 & 7.4236 & 6.98528 \\
PPT & 33 & 3.12 & 76.34 & 26.9391 & 19.42161 \\
\hline \multicolumn{5}{c}{ Sumber: Data yang diolah dengan SPSS 17.0 }
\end{tabular}

Berdasarkan Tabel 2 di atas, diketahui output tampilan SPSS menunjukkan nilai minimum gross profit margin sebesar 291,175. Nilai maksimum sebesar 796,792 sedangkan nilai standar deviasi sebesar 2,35810 dengan rata-rata 2,5610. Working capital turnover memiliki nilai minimum sebesar 707,344 . Nilai maksimum sebesar 783,802 sedangkan nilai standar deviasi sebesar 2,09810 dengan rata-rata 1,0010. Cash turnover memiliki nilai minimum sebesar 0,06. Nilai maksimum sebesar 6,03 sedangkan nilai standar deviasi sebesar 1,11441 dengan rata-rata 7,4236. Inventory turnover memiliki nilai minimum sebesar 0,11. Nilai maksimum sebesar 29,33 sedangkan nilai standar deviasi sebesar 6,98528 dengan rata-rata 7,4236. Receivable turnover memiliki nilai minimum sebesar 3,12. Nilai maksimum sebesar 76,34 sedangkan nilai standar deviasi sebesar 19,42161 dengan rata-rata 26,9391.

\section{Uji asumsi klasik}

Sebelum dilakukan analisis regresi linier sederhana untuk mengetahui ada atau tidaknya pengaruh antara variabel independen terhadap variabel dependen, maka data penelitian harus terlebih dahulu dilakukan uji asumsi klasik. Uji asumsi klasik yang perlu dilakukan disesuaikan dengan jenis pengujian yang dibutuhkan dalam penelitian yang bersangkutan.

Uji ini bertujuan untuk menguji apakah model regresi, variabel bebas dan variabel terikatnya berdistribusi normal. Normalitas data dapat dilihat dengan menggunakan uji normal kolmogorovsmirnov. Kriteria pengambilan keputusannya adalah jika sig $>0,05$ maka data berdistribusi normal dan jika sig $<0,05$ maka data tidak terdistribusi normal
(Ghozali, 2012). Hasil uji normalitas sebelum outlier dapat dilihat pada Tabel 3 sebagai berikut:

Tabel 3

Uji Normalitas (sebelum outlier)

\begin{tabular}{lc}
\hline & $\begin{array}{c}\text { Unstandardized } \\
\text { Residual }\end{array}$ \\
\hline Kolmogorov-Smirnov Z & 2.626 \\
Asymp. Sig. (2-tailed) & .000 \\
\hline \multicolumn{1}{c}{ Sumber: Data yang diolah dengan SPSS 17.0}
\end{tabular}

Berdasarkan hasil uji normalitas sebelum outlier data pada Tabel 3 terlihat bahwa nilai signifikansi jauh di bawah 0,05 sehingga dapat disimpulkan bahwa data residual tidak berdistribusi normal. Hasil tersebut menandakan bahwa perlunya mengeliminasi data-data outlier agar dapat berdistribusi normal.

Menurut (Ghozali, 2012) eliminasi outlier adalah kondisi observasi suatu data yang memiliki karakteristik unik sangat berbeda jauh dari observasi lainnya dan muncul dalam bentuk nilai ekstrim baik untuk variabel tunggal maupun kombinasi. Setelah dilakukan pengeliminasian terhadap data outlier, maka diperoleh nilai signifikansi di atas 5\%. Hasil uji normalitas yang dilakukan setelah outlier dapat dilihat pada Tabel 4 sebagai berikut:

Tabel 4

Uji Normalitas (setelah outlier)

\begin{tabular}{lc}
\hline & $\begin{array}{c}\text { Unstandardized } \\
\text { Residual }\end{array}$ \\
\hline Kolmogorov-Smirnov Z & 0.789 \\
Asymp. Sig. (2-tailed) & .562 \\
\hline \multicolumn{2}{c}{ Sumber: Data yang diolah dengan SPSS 17.0}
\end{tabular}

Berdasarkan Tabel 4 di atas diketahui nilai dari Kolmogorov-Smirnov $Z$ sebesar 0,789 dan nilai signifikansinya adalah 0,562 . Nilai signifikansi tersebut lebih besar dari 0,05 atau 5\% sehingga dapat disimpulkan bahwa data residual telah berdistribusi normal.

\section{Pengujian hipotesis}

Pengujian hipotesis dilakukan dengan menggunakan analisis regresi linier sederhana serta uji parsial (uji statistik t) yang diolah dengan menggunakan SPSS versi 17. Uji statistik menunjukkan seberapa jauh pengaruh satu variabel independen secara individual dalam menerangkan variasi variabel dependen.

Hipotesis pertama yang diajukan dalam penelitian ini menyatakan bahwa perputaran modal kerja berpengaruh positif terhadap kinerja perusahaan. Hipotesis ini dapat didukung apabila nilai 
signifikansinya menunjukkan nilai $<0,05$ dan tidak dapat didukung jika sebaliknya. Hasil uji signifikansi$\mathrm{t}$ model persamaan pertama dalam penelitian ini dapat dilihat pada Tabel 5 sebagai berikut:

Tabel 5

Hasil uji H1

\begin{tabular}{lccl}
\hline \multicolumn{1}{c}{ Variabel } & $\mathrm{B}$ & Standar Eror & Sig. \\
\hline Konstanta & 2.15110 & 4.3189 & .000 \\
PMK & .408 & .188 & .038 \\
\hline R-Square & & & .132 \\
Adjusted R-Square & & .104 \\
\hline \multicolumn{4}{c}{ Sumber: Data diolah dengan SPSS 17.0 }
\end{tabular}

Data diolah berdasarkan SPSS 17.0 yang mana sig. pada $\alpha$ merupakan hasil dari sig. 2-tailed yakni $\alpha 5 \%$. Berdasarkan pengujian hipotesis, jenis uji yang dilakukan dalam penelitian ini adalah satu arah (1tailed). Menurut Holipah (2011) untuk menghitung nilai signifikansi satu arah (1-tailed) maka dapat menggunakan cara yaitu nilai signifikansi yang diperoleh dari output SPSS dibagi dua sehingga nilai signifikansi pada $\alpha$ yang digunakan adalah $0,038 / 2=$ 0,019 . Hipotesis pertama dalam penelitian ini diuji dengan uji 1-tailed karena hipotesis telah memiliki arah yakni positif. Dari Tabel 5 dapat dilihat bahwa sig. $0,019<0,05$ dan nilai $\beta=0,408$ (positif) maka hipotesis pertama $(\mathrm{H} 1)$ terdukung.

Nilai Persamaan regresi dapat ditulis sebagai berikut: $\mathrm{GPM}=2,151+0,048$ PMK. Persamaan tersebut menunjukkan pengaruh antara variabel independen terhadap variabel dependen. Definisi dari persamaan regresi tersebut adalah rata-rata gross profit margin perusahaan sebesar 2,151 akan meningkat positif sebesar 0,048 jika variabel perputaran modal kerja naik 1 satuan. Koefisien determinasi (adjusted $R^{2}$ ) sebesar 0,104 hal ini berarti hanya $10,4 \%$ variabel dependen yaitu gross profit margin dapat dijelaskan oleh variabel independen yaitu perputaran modal kerja, sedangkan sisanya $(100 \%-10,4 \%=89,6 \%)$ dijelaskan oleh variabel lain.

Hipotesis kedua yang diajukan dalam penelitian ini menyatakan bahwa perputaran kas berpengaruh positif terhadap kinerja perusahaan. Hipotesis ini dapat didukung apabila nilai signifikansinya menunjukan nilai $<0,05$ dan tidak dapat didukung jika sebaliknya. Hasil uji signifikansi-t model persamaan kedua dalam penelitian ini dapat dilihat pada Tabel 6 .

Data diolah berdasarkan SPSS 17.0 yang mana sig. pada $\alpha$ merupakan hasil dari sig. 2-tailed yakni $\alpha 5 \%$. Berdasarkan pengujian hipotesis, jenis uji yang dilakukan dalam penelitian ini adalah satu arah (1tailed). Menurut Holipah (2011) untuk menghitung nilai signifikansi satu arah (1-tailed) maka dapat menggunakan cara yaitu nilai signifikansi yang diperoleh dari output SPSS dibagi dua sehingga nilai signifikansi pada $\alpha$ yang digunakan adalah $0,463 / 2=$ 0,2315 . Hipotesis kedua dalam penelitian ini diuji dengan uji 1-tailed karena hipotesis telah memiliki arah yakni positif. Dari tabel 6 dapat dilihat bahwa sig. $0,2315>0,05$ dan nilai $\beta=2,8019$ (positif) maka hipotesis kedua (H2) tidak terdukung walaupun arahnya positif tetapi nilai signifikansinya lebih besar dari $5 \%$.

Tabel 6

Hasil Uji H2

\begin{tabular}{lccc}
\hline \multicolumn{1}{c}{ Variabel } & B & Standar Eror & Sig. \\
\hline Konstanta & 3.12210 & 8.6309 & .001 \\
PK & 2.8019 & 3.7679 & .463 \\
\hline R-Square & & & .018 \\
Adjusted R-Square & & & .014 \\
\hline
\end{tabular}

Sumber: Data diolah dengan SPSS 17.0

Nilai persamaan regresi dapat ditulis sebagai berikut: GPM $=3,122+2,801$ PK. Persamaan di atas menunjukkan pengaruh antara variabel independen terhadap variabel dependen. Definisi dari persamaan regresi tersebut adalah rata-rata gross profit margin perusahaan sebesar 3,122 dan akan meningkat sebesar 2,801 jika variabel perputaran kas naik 1 satuan. Koefisien determinasi (adjusted $R^{2}$ ) sebesar 0,014 hal ini berarti hanya 1,4\% variabel dependen yaitu gross profit margin dapat dijelaskan oleh variabel independen yaitu perputaran kas, sedangkan sisanya $(100 \%-1,4 \%=98,6 \%)$ dijelaskan oleh variabel lain .

Hipotesis ketiga yang diajukan dalam penelitian ini menyatakan bahwa perputaran persediaan berpengaruh positif terhadap kinerja perusahaan. Hipotesis ini dapat didukung apabila nilai signifikansinya menunjukan nilai $<0,05$ dan tidak dapat didukung jika sebaliknya. Hasil uji signifikansi$\mathrm{t}$ model persamaan ketiga dalam penelitian ini dapat dilihat pada Tabel 7 sebagai berikut:

Tabel 7

Hasil uji H3

\begin{tabular}{lccl}
\hline \multicolumn{1}{c}{ Variabel } & B & Standar Eror & Sig. \\
\hline Konstanta & 3.41910 & 5.7639 & .000 \\
PP & 1.1609 & 5.6958 & .050 \\
\hline R-Square & & & .118 \\
Adjusted R-Square & & .090 \\
\hline \multicolumn{4}{c}{ Sumber: Data diolah dengan SPSS 17.0 }
\end{tabular}

Data diolah berdasarkan SPSS 17.0 yang mana sig. pada $\alpha$ merupakan hasil dari sig. 2-tailed yakni $\alpha 5 \%$. 
Berdasarkan pengujian hipotesis, jenis uji yang dilakukan dalam penelitian ini adalah satu arah (1tailed). Menurut Holipah (2011) untuk menghitung nilai signifikansi satu arah (1-tailed) maka dapat menggunakan cara yaitu nilai signifikansi yang diperoleh dari output SPSS dibagi dua sehingga nilai signifikansi pada $\alpha$ yang digunakan adalah $0,050 / 2=$ 0,025 . Hipotesis ketiga dalam penelitian ini diuji dengan uji 1-tailed karena hipotesis telah memiliki arah yakni positif. Dari Tabel 7 dapat dilihat bahwa sig. $0,025<0,05$ dan nilai $\beta=1,160$ (positif) maka hipotesis ketiga (H3) terdukung.

Nilai Persamaan regresi dapat ditulis sebagai berikut: $\mathrm{GPM}=3,419+1,160$ PP. Persamaan di atas menunjukkan pengaruh antara variabel independen terhadap variabel dependen. Definisi dari persamaan regresi tersebut adalah rata-rata gross profit margin perusahaan sebesar 3,419 dan akan meningkat sebesar 1,160 jika variabel perputaran persediaan naik 1 satuan. Koefisien determinasi (adjusted $R^{2}$ ) sebesar 0,090 hal ini berarti hanya $9 \%$ variabel dependen yaitu gross profit margin dapat dijelaskan oleh variabel independen yaitu perputaran persediaan, sedangkan sisanya $(100 \%-9 \%=91 \%)$ dijelaskan oleh variabel lain.

Hipotesis keempat yang diajukan dalam penelitian ini menyatakan bahwa perputaran piutang berpengaruh positif terhadap kinerja perusahaan. Hipotesis ini dapat didukung apabila nilai signifikansinya menunjukan nilai $<0,05$ dan tidak dapat didukung jika sebaliknya. Hasil uji signifikansit model persamaan keempat dalam penelitian ini dapat dilihat pada Tabel 8 sebagai berikut:

Tabel 8

Hasil uji H4

\begin{tabular}{lccl}
\hline \multicolumn{1}{c}{ Variabel } & B & Standar Eror & Sig. \\
\hline Konstanta & 4.20710 & 6.2239 & .000 \\
PPT & 6.1218 & 1.8848 & .003 \\
\hline R-Square & & & .254 \\
Adjusted R-Square & & & .230 \\
\hline
\end{tabular}

Sumber: Data diolah dengan SPSS 17.0

Data diolah berdasarkan SPSS 17.0 yang mana sig. pada $\alpha$ merupakan hasil dari sig. 2-tailed yakni $\alpha 5 \%$. Berdasarkan pengujian hipotesis, jenis uji yang dilakukan dalam penelitian ini adalah satu arah (1tailed). Menurut Holipah (2011) untuk menghitung nilai signifikansi satu arah (1-tailed) maka dapat menggunakan cara yaitu nilai signifikansi yang diperoleh dari output SPSS dibagi dua sehingga nilai signifikansi pada $\alpha$ yang digunakan adalah $0,003 / 2=$
0,0015. Hipotesis keempat dalam penelitian ini diuji dengan uji 1-tailed karena hipotesis telah memiliki arah yakni positif. Dari table 8 dapat dilihat bahwa sig. $0,0015<0,05$ dan nilai $\beta=6,1218$ (positif) maka hipotesis keempat (H4) terdukung.

Tabel 9

Analisis Data

\begin{tabular}{lcc}
\hline \multicolumn{1}{c}{ Hipotesis } & Sig. & Hasil \\
\hline $\begin{array}{l}\text { H1: Perputaran modal kerja berpengaruh } \\
\text { positif terhadap kinerja perusahaan. }\end{array}$ & 0,019 & Terdukung \\
$\begin{array}{l}\text { H2: Perputaran kas berpengaruh positif } \\
\text { terhadap kinerja perusahaan. }\end{array}$ & 0,2315 & Tidak Terdukung \\
$\begin{array}{l}\text { H3: Perputaran persediaan berpengaruh } \\
\text { positif terhadap kinerja perusahaan. }\end{array}$ & 0,025 & Terdukung \\
$\begin{array}{l}\text { H4: Perputaran piutang berpengaruh positif } \\
\text { terhadap kinerja perusahaan }\end{array}$ & 0,0015 & Terdukung \\
\hline \multicolumn{2}{c}{ Sumber: Diolah Sendiri } \\
\hline
\end{tabular}

Nilai Persamaan regresi dapat ditulis sebagai berikut: GPM $=4,2071+6,1218$ PPT. Persamaan diatas menunjukkan pengaruh antara variabel independen terhadap variabel dependen. Definisi dari persamaan regresi tersebut adalah rata-rata gross profit margin perusahaan sebesar 4,2071 dan akan meningkat sebesar 6,1218 jika variabel perputaran piutang naik 1 satuan. Koefisien determinasi (adjusted $R^{2}$ ) sebesar 0,230 hal ini berarti hanya $23 \%$ variabel dependen yaitu gross profit margin dapat dijelaskan oleh variabel independen yaitu perputaran piutang, sedangkan sisanya $(100 \%-23 \%=77 \%)$ dijelaskan oleh variabel lain.

\section{Pembahasan}

Penelitian ini bertujuan untuk meneliti pengaruh modal kerja perusahaan (perputaran modal kerja, perputaran kas, perputaran persediaan, dan perputaran piutang), terhadap kinerja perusahaan (gross profit margin).

\section{Pengaruh perputaran modal kerja terhadap kinerja perusahaan}

Berdasarkan hasil pengujian hipotesis yang telah dijelaskan pada Tabel 5 menunjukkan bahwa terdapat pengaruh positif dan signifikan antara perputaran modal kerja terhadap gross profit margin. Hal ini menyatakan bahwa hipotesis pertama (H1) terdukung. Hasil tersebut menandakan bahwa keefektifan dalam penggunaan modal kerja sehingga adanya peningkatan produktfitas yang diikuti dengan peningkatan 
penjualan atau pendapatan pada perusahaan, semakin tinggi penjualan maka profitabilitas perusahaan meningkat sehingga berdampak baik bagi kinerja perusahaan. Hal ini didukung oleh penelitian Yang et al. (2014) yang menunjukkan secara parsial variabel perputaran modal kerja berpengaruh positif signifikan terhadap kinerja perusahaan.

\section{Pengaruh perputaran kas terhadap kinerja perusahaan}

Berdasarkan hasil pengujian hipotesis yang telah dijelaskan pada Tabel 6 menunjukan bahwa terdapat tidak berpengaruh positif antara perputaran kas terhadap gross profit margin. Hal ini menyatakan bahwa hipotesis kedua (H2) tidak terdukung. Hasil tersebut menandakan bahwa penurunan produktivitas yang diikuti dengan sedikitnya pendapatan atau penjualan, serta rendahnya efisiensi penggunaan kas menunjukkan bahwa kinerja perusahaan kurang baik sehingga perusahaan tidak mengalami laba. Hal ini didukung oleh penelitian Knight et al. (2013) yang menunjukkan secara parsial variabel perputaran kas tidak berpengaruh signifikan terhadap kinerja perusahaan.

\section{Pengaruh perputaran persediaan terhadap kinerja perusahaan}

Berdasarkan hasil pengujian hipotesis yang telah dijelaskan pada Tabel 7 menunjukan bahwa terdapat pengaruh positif dan signifikan antara perputaran persediaan terhadap gross profit margin. Hal ini menyatakan bahwa hipotesis ketiga (H3) terdukung. Hasil tersebut menandakan bahwa perusahaan mampu mengontrol modal yang ada pada persediaan dengan baik, semakin tinggi perputaran persediaan maka semakin besar pula keuntungan yang diperoleh dan semakin menunjukkan kinerja perusahaan yang baik. Hal ini didukung oleh penelitian Makori et al. (2013) yang menunjukkan secara parsial variabel perputaran persediaan berpengaruh signifikan terhadap kinerja perusahaan.

\section{Pengaruh perputaran piutang terhadap kinerja perusahaan}

Berdasarkan hasil pengujian hipotesis yang telah dijelaskan pada Tabel 8 menunjukan bahwa terdapat pengaruh positif dan signifikan antara perputaran piutang terhadap gross profit margin. Hal ini menyatakan bahwa hipotesis keempat $(\mathrm{H} 4)$ terdukung.
Hasil tersebut menandakan bahwa perusahaan mampu mengukur dengan baik dalam penggunaan dana yang tersedia yang tercermin dalam perputaran modal serta perusahaan berhasil dalam menagih piutang yang ada. Semakin cepat perputaran piutang maka menandakan bahwa modal dapat digunakan secara efisien dan semakin baik pula kinerja perusahaan. Hal ini didukung oleh penelitian Solano et al. (2013) yang menunjukkan secara parsial variabel perputaran piutang berpengaruh signifikan terhadap kinerja perusahaan.

\section{Kesimpulan}

Berdasarkan hasil penelitian di atas mengenai pengaruh modal kerja terhadap kinerja perusahaan pada perusahaan perdagangan eceran yang terdaftar di Bursa Efek Indonesia (BEI) periode 2012-2016. Dari empat hipotesis yang dijabarkan tiga hipotesis terdukung dan satu hipotesis tidak terdukung. Kesimpulan dari penelitian ini adalah sebagai berikut:

Hasil pengujian secara parsial menunjukkan bahwa perputaran modal kerja berpengaruh positif signifikan terhadap kinerja perusahaan (gross profit margin). Hasil tersebut menunjukkan bahwa keefektifan dalam penggunaan modal kerja sehingga adanya peningkatan produktfitas yang diikuti dengan peningkatan penjualan atau pendapatan pada perusahaan, semakin tinggi penjualan maka profitabilitas perusahaan meningkat sehingga berdampak baik bagi kinerja perusahaan.

Hasil pengujian secara parsial menunjukkan bahwa perputaran kas tidak berpengaruh positif signifikan terhadap kinerja perusahaan (gross profit margin). Hasil tersebut menunjukkan bahwa penurunan produktivitas yang diikuti dengan sedikitnya pendapatan atau penjualan pada perusahaan, serta rendahnya efisiensi penggunaan kas menunjukkan bahwa kinerja perusahaan kurang baik sehingga perusahaan tidak mengalami laba. Perusahaan dalam menjalankan operasional membutuhkan dana yang besar. Kebutuhan dana ini tidak dapat sepenuhnya dipenuhi dengan menggunakan modal saja, maka perusahaan harus meningkatkan volume penjualannya, baik penjualan secara tunai maupun penjualan secara kredit dan juga perusahaan harus melakukan pengaturan terhadap pengeluaran dan penerimaan kas sehingga perusahaan mendapatkan laba.

Hasil pengujian secara parsial menunjukkan bahwa perputaran persediaan berpengaruh positif signifikan 
terhadap kinerja perusahaan (gross profit margin). Hasil tersebut menunjukkan bahwa perusahaan mampu mengontrol modal yang ada pada persediaan dengan baik, semakin tinggi perputaran persediaan maka semakin besar pula keuntungan yang diperoleh dan semakin menunjukkan kinerja perusahaan yang baik.

Hasil pengujian secara parsial menunjukkan bahwa perputaran piutang berpengaruh positif signifikan terhadap kinerja perusahaan (gross profit margin). Hasil tersebut menunjukkan bahwa perusahaan mampu mengukur dengan baik dalam penggunaan dana yang tersedia yang tercermin dalam perputaran modal serta perusahaan berhasil dalam menagih piutang yang ada, semakin cepat perputaran piutang maka menandakan bahwa modal dapat digunakan secara efisien dan semakin baik pula kinerja perusahaan.

Pada penelitian ini terdapat beberapa keterbatasan. Pertama, penelitian ini hanya menggunakan sampel perusahaan di sektor perdagangan eceran di BEI sehingga belum mencakup semua sektor-sektor industri. Kedua, penelitian ini hanya menggunakan empat variabel bebas yaitu perputaran modal kerja, perputaran kas, perputaran persediaan, dan perputaran piutang.

Tujuan mengelola modal kerja adalah membiayai operasi perusahaan sehari-hari sehingga menghasilkan laba. Pada penelitian ini dapat disimpulkan bahwa manajemen perusahaan hendaknya memanfaatkan modal kerjanya secara efisien sehingga bisa meningkatkan kinerja pada perusahaan. Keberhasilan sebuah perusahaan ditentukan oleh seberapa efisien perusahaan tersebut menggunakan sumber daya yang dimiliki untuk memperoleh pendapatan maksimal. Pihak perusahaan harus berperan aktif saat menentukan besarnya dana, cara mendapatkan dana, dan harus mengalokasikan pada berbagai jenis aktiva yang menghasilkan dan dapat mengendalikannya, sehingga diperoleh suatu kombinasi sumber penggunaan dana yang seimbang dan efisien karena manajemen modal kerja berkaitan erat dengan pembelanjaan.

Saran untuk penelitian selanjutnya diharapkan dapat menggunakan sampel perusahaan di sektor yang lebih luas, tidak hanya pada sektor perdagangan eceran saja agar kedepannya penelitian mampu mendapatkan hasil yang lebih maksimal. Selanjutnya dapat menambahkan variabel independen lain dalam penelitian karena keempat variabel independen yang diteliti terhadap kinerja perusahaan kurang dari $50 \%$ atau kurang mewakili.

\section{References}

Amstrong, J. Scott. (2000). Sales Forecast For Existing Consumer Products and Services: Do Purchase Intentions Contribute to Accuracy? The Wharton School, University of Pennsylvinia, Philadelphia.

C. Kim, D. C. Mauer, and A. E. Sherman, "The determinants of corporate liquidity: theory and evidence," The Journal of Financial and Quantitative Analysis, vol. 33, no. 3, pp. 335-359, 1998.

Darsono dan Ashari. 2005. Pedoman Praktis Memahami Laporan Keuangan. Jakarta: Salemba Empat.

Esra, Martha Ayerza dan Prima Apriweni. (2002). Manajemen Modal Kerja. Jurnal Ekonomi Perusahaan. STIE iBii.

Ghazi et al. (2013). Working Capital Management and Firm Performance in Karachi Stock Exchange (KSE). Air University Islamabad (44000), Pakistan.

Ghozali, I. (2011). Aplikasi Analisis Multivariate dengan Program SPSS. Semarang: Universitas Diponegoro.

Ghozali, I. (2011). Aplikasi Analisis Multivariate dengan Program SPSS. Semarang: Universitas Diponegoro.

David, Hunger J dan Wheelen Thomas L. 2003. Manajemen Strategis. Yogyakarta: ANDI.

Jensen, M., and Meckling, W. (1976). Theory of the firm: Managerial behavior, agency costs, and ownership structure. Journal of Financial Economics, 3: 305-360.

Kasmir. (2011). Analisa laporan Keuangan (Ed. 1). Jakarta: Rajawali Pers.

Knight et al. (2013). Investment and financing constraints in China: does working capital management make a difference? Durham University, Durham.

Makori, D. M., \& Jagongo, A. (2013). Working Capital Management and Firm Profitability: Empirical Evidence from Manufacturing and Construction Firms Listed on Nairobi Securities Exchange, Kenya. International Journal of Accounting and Taxation, Vol. 1 No. 1.

Munawir, S. (2004). Analisis Laporan Keuangan. Edisi Keempat. Yogyakarta: Liberty

Rahma, Aulia. (2013). Analisis pengaruh managemen modal kerja terhadap profitabilitas perusahaan (Studi pada perusahaan PMA \& PMDN yang Listing di BEI periode 2004-2008).

Riyanto, Bambang. (2001). Dasar Dasar Pembelajaran Perusahaan. Yogyakarta: BPFE.

S. Ba nos-Caballero, P. J. Garc' 1a-Teruel, and P.Mart'inez-Solano, "Working capital management in SMEs," Accounting and Finance, vol. 50, no. 3, pp. 511-527, 2010.

Sarwono, J. (2013). Jurus Ampuh SPSS. Jakarta: PT Elex Media Komputindo.

Sugiyono. (2009). Metode Penelitian Bisnis. Bandung: Alfabeta. 
Solano et al. (2013). Working capital management, corporate performance, and financial constraints. Department of Management and Finance, Faculty of Economics and Business, University of Murcia, Murcia, Spain.

Syamsyuddin. 2009. Manajemen Keuangan Perusahan. Jakarta : PT. Raja Grafindo Persada.
Widarjono, Agus (2007). Ekonometrika: Teori dan Aplikasi Untuk Ekonomi dan Bisnis, edisi kedua. Yogyakarta: Ekonisia FE Universitas Islam Indonesia.

Yang et al. (2014). Research Article Working Capital Management, Corporate Performance, and Strategic Choices of the Wholesale and Retail Industry in China. China : Business School of Hunan University, Changsha 410082.

Wernerfelt, B. (1984). A resource-based view of the firm. 